\title{
Suomi vieraana kielenä -oppikirjojen sisältöjen suhde oman aikansa ilmiöihin: Johannes Aavikin Praktilik Soome keele õpetus (1902) ja Béla Györffyn Gyakorlati Finn Nyelvkönyv (1939)
}

\author{
MARJUT VEHKANEN \\ Helsingin yliopisto
}

Tiivistelmä. Artikkelini käsittelee Johannes Aavikin (1902) Praktilik Soome keele ópetus (Käytännöllinen suomen kielen opetus) ja Béla Györffyn (1939) Gyakorlati Finn Nyelvkönyv (Suomen kielen harjoituskirja) -oppikirjatekstien aihepiirejä ja oppikirjojen käyttäjäryhmiä. Tarkastelen näiden kahden oppikirjan sisältöjen suhdetta oman aikansa ilmiöihin. Tutkin kulttuurihistoriallisesta näkökulmasta käsin, löytyykö teksteistä esimerkiksi kielisukulaisuuteen viittaavia ratkaisuja tai mahdollisia yhtymäkohtia ilmestymisajankohtien historiallisiin todellisuuksiin. Tavoitteeni on oppikirjatekstien aihepiirejä vertailemalla avata näkökulmia kirjoittajien ajatusmaailmaan ja heidän oppimiskäsityksiinsä sekä kirjoille asetettuihin mahdollisiin erityistehtäviin niiden ilmestymisajankohtina. Kirjoittajat ovat sidoksissa aikaansa - tässä tapauksessa oppikirjan ilmestymisajankohtaan ja kirjoitusprosessin aikaiseen todellisuuteen ja sen luomiin vaatimuksiin.

Avainsanat: suomi vieraana kielenä; S2-oppikirjatekstit; lähtökieli; viro; unkari 


\section{Johdanto}

Historian saatossa oppikirjojen tekstien sisältöihin ja niihin kirjautuneihin tekstilajeihin ovat vaikuttaneet kirjojen ilmestymisajankohdat, oppikirjojen kirjoittajien taustat, opiskelijat opiskelutarpeineen, kirjojen sisällölliset tarkoitusperät sekä opetuspedagogiikka. Kun kirjoja tutkitaan historiallisesta näkökulmasta käsin, pitää huomioida myös ajankohtina käytössä olleet kieli- ja kirjoituskäytänteet. Tekstit ovat aina osa tekstien verkkoa, mutta ne ovat myös osa historiaa, joka aktivoituu nykyisyyden lukuhetkellä (Mäntynen 2003: 25). Oppikirjatekstien merkitykset avautuvat vasta niiden laajemmassa kontekstissa ja määräytyvät tekstien käyttöyhteydestä, käyttäjistä ja esiintymispaikasta (Karvonen 1995: 206; Hiidenmaa 2003: 163). S2-oppikirjojen tekstit ovat malleja suomea opiskeleville opiskelijoille: niihin on kerätty tietoa suomen kielen rakenteesta, vuorovaikutuksesta sekä suomalaisesta kulttuurista ja yhteiskunnasta (Tanner 2012: 8). Tekstit ovat aina siis myös suhteessa johonkin aikaisempaan tekstiin tai sen uuteen tulkintaan. Eri tekstilajit kertovat siitä, mikä tietyssä sosiaalisessa toiminnassa on keskeistä ja millaisia vuorovaikutussuhteita niihin rakentuu (Heikkinen \& Voutilainen 2012: 19). Niitä voidaan pitää myös omalla tavallaan sosiokulttuurisen kontekstin ja tekstien kielellisten piirteiden yhdistäjänä (Kalliokoski 2002: 147-149).

Oppikirjan sisällöltä vaaditaan sekä selkeyttä että havainnollisuutta oppimisen tueksi. Kirjoittajat lainaavat teksteihinsä valmista tietoa ja tekstikatkelmia muista kirjoituksista, mutta he tuottavat myös itse paljon omaa tekstiä oppikirjoihinsa (Hiidenmaa 2003: 216-219; Karvonen 1995: 12, 209-210; Saukkonen 2001: 142-145, 190). Aikuisopiskelijoiden 1900-luvun alussa kirjoitettujen suomi toisena ja vieraana kielenä -oppikirjojen sisällöt tarjoavat kielioppipainotteisesti rakennettuja, kirjojen käyttäjäryhmille sopivia tekstisisältöjä: kaupunkielämää ja turismia, yhteiskunnallisia faktatietoja, sotaan liittyviä aiheita sekä suomalaista kulttuurihistoriaa. Kaunokirjallisten tekstien avulla kieltä on opetettu niin lapsille kuin aikuisillekin. Maaseutu näyttäytyy aikuisten 
oppikirjoissa usein juuri kaunokirjallisten katkelmien kautta. Tutkimuksen kohteina olevien aikuisten S2-oppikirjojen sisältöjen erittely mahdollistaa päätelmien tekemisen näiden kirjojen aihepiireistä sekä toisaalta yksittäisten, tiettyyn ajankohtaan liittyvien piirteiden havaitsemisesta. Pystyn tässä tutkimuksessa kulttuurihistoriallisen näkökulman avulla pureutumaan siihen, miten ajankohtaiset asiat ja elinympäristö heijastuvat teksteihin ja millaisilla sisällöillä lukijaa houkutellaan opiskelemaan ja tutustumaan opiskeltavaan kieleen ja sen kulttuuriin.

Selvitän kahden maantieteellisesti etäällä toisistaan kirjoitetun, eriikäisen oppikirjatekstin kytköksiä aikansa tekstikonventioihin. Tutkin, mikä teksteissä on erilaista ja mikä samaa, kun tarkastelen Aavikin (1902) ja Györffyn (1939) oppikirjatekstejä, joiden julkaisuajankohdat poikkeavat toisistaan lähes 40 vuotta. Aavikin oppikirjan ilmestyessä Suomi eli autonomian ajan loppupuolta Venäjän yhteydessä. Kolmekymmentä vuotta myöhemmin Györffyn kirjan ilmestyessä Suomessa käytiin talvisotaa. Aavikin oppikirjan sisältö on kauttaaltaan Euroopassa sata vuotta (1840-1940) vaikuttaneeseen kielioppi-käännösmenetelmään tukeutuvaa, kieliopin omaksumiseen, lukemiseen, kirjoittamiseen ja kääntämiseen keskittyvää viron ja suomen kielen vertailua, kun taas Györffyn kirjan ilmestymisen aikoihin S2-oppikirjoja kirjoitettiin edelleenkin pääosin kielioppipainotteisesti, mutta kirjojen toteutuksessa käytettiin jo kuitenkin useita eri opetusmenetelmiä (Richards \& Rodgers 2007: 9-18; Vehkanen 2015: 48-50, 216; Vehkanen 2017: 244). Kohdittain vertaan nyt tutkittavana olevia teoksia myös muihin vanhoihin S2-oppikirjoihin.

Artikkelini etenee seuraavalla tavalla. Luvussa 2 kuvaan aineiston ja lähestymistapani. Luvun 3 alussa pohdiskelen oppikirjojen tekstejä yleisellä tasolla ja siirryn sitten luvuissa 3 ja 4 tarkastelemaan Aavikin ja Györffyn oppikirjojen tekstien sisältöjä ja niiden aihepiirejä. Luvussa 5 teen koontia kirjojen sisältöihin esittämiini kysymyksiin. 


\section{Tutkimusaineisto ja menetelmä}

Artikkelin tutkimusaineiston muodostavat suomen sukukielten puhujille, vironkielisille ja unkarinkielisille opiskelijoille, kirjoitetut suomi vieraana kielenä -oppikirjat. Johannes Aavikin (1902) Praktilik Soome keele õpetus julkaistiin Yrjö Weilinin -kustantamossa Suomessa. Béla Györffyn (1939) Gyakorlati Finn Nyelvkönyv taas Harangszó Kiadása -kustantamossa Unkarissa. Tutkitut oppikirjat kuuluvat väitöskirjani tutkimusaineiston 50 muun vuosina 1866-1953 ilmestyneen S2-oppikirjan joukkoon (Vehkanen 2015: 14). Tutkimuskohteena olevien kirjojen tekstien sisällöt eroavat historiansa, kulttuurinsa ja maantieteellisen etäisyytensä vuoksi toisistaan (Vehkanen 2015: 59). Väitöskirjani aineiston ajankohdan S2-oppikirjojen nimistä ei vielä tuolloin ilmennyt, että kirjat oli kirjoitettu suomen kieltä ulkomailla opiskeleville, vaan niitä nimitettiin yksinkertaisesti vain suomen kielen oppikirjoiksi nykyisestä suomi vieraana kielenä -termistä poiketen (Korhonen 2012: 15; Elomaa 2009: 19; Suni 2008: 30-31).

Johannes Aavik mainitsee esipuheessaan laatineensa oppikirjansa suomen kielestä kiinnostuneille virolaisille opiskelijoille (Aavik 1902: esipuhe). Béla Györffyn oppikirjan kohderyhmänä olivat Unkarin luterilaiset teologian opiskelijat (Vehkanen 2017: 248).

Tarkastelen tapaustutkimuksena Aavikin ja Györffyn oppikirjojen tekstien sisältöjä, vertailen niiden tarkoitusperiä ja niiden sopivuutta kirjoittajien mainitsemille käyttäjäryhmille. Tutkin, kuinka kirjojen erilaiset käyttötarkoitukset säätelevät näissä oppikirjoissa tekstien sisältöjä ja mikä niiden suhde on ympäröivään yhteiskuntaan, ilmestymisajankohtaan sekä kirjojen käyttäjäkuntiin. Artikkelissani luokittelen ja vertailen aineistoa, kirjojen esittämistapoja ja peilaan niitä ajan ilmiöihin. Menetelmänä on tulkintaan ja päättelyyn perustuva laadullinen aineistolähtöinen sisällönanalyysi, jossa etenen aineiston havainnoista kohti laajempaa kokonaisuutta. Selvittämällä oppikirjojen sisältöjen tapoja kuvata omaa aikaansa ja niille asetettuja mahdollisia erityistehtäviä uskon pystyväni luomaan mielenkiintoisen näkökulman siihen, 
miten oppikirjojen sisällöt suhteutuvat niiden ilmestymisajankohdan ilmiöihin (Tuomi \& Sarajärvi 2013: 95-96, 108-109, 123-124; Hirsjärvi ym. 2013: 126-128).

\section{Kielten oppikirjojen teksteistä}

Kielten oppikirjojen tekstit ovat useimmiten kielioppiasiaan sidottua fiktiota, faktaan ja fiktioon pohjautuvaa kirjoittajan laatimaa tai lainaamaa kerrontaa, autenttisia tekstikatkelmia ja erilaisia dialogityyppejä. Ne koostuvat useista eri tekstilajeista. Opetuksen päämääränä on yleensä opetettavan kielioppiasian omaksuminen ja oppiminen. Teksteillä on kuitenkin oma merkittävä sijansa oppikirjoissa, sillä ne ovat samalla sidoksissa myös oman aikansa historiaan ja kulttuuriin (Melander 2001: 117). Suomessa varhaiset lukukirjojen tekstit sisälsivät kuvauksia oman aikansa yhteiskunnasta ensin uskonnon, sitten hyödyllisten neuvojen ja Pohjolassa myös 1800-luvun lopulta lähtien satujen ja hölmöläistarinoiden avulla.

Äidinkielen oppikirjoissa oman maan olosuhteita ja kulttuuria kuvataan positiivisesti. Kuvauksissa oikeudenmukaiset ja hyvät hallitsijat taistelevat vierasta vihollista vastaan. Tämä kertoo kirjoittajan asenteista sekä omaa kulttuuriaan että muita kulttuureita kohtaan. Ruotsalainen tutkija Luis Ajagán-Lester kutsuu lukukirjojen sisältämiä kuvauksia "kolonialistisiksi matkakertomuksiksi" aina renessanssin ajalta 1950-luvulle saakka. Kuvausten kirjoittajina ovat usean vuosisadan ajan olleet lähinnä sotilashenkilökunta, liikemiehet ja kirkonmiehet. Ajagán-Lesterin esimerkki on 1850-luvun lopulta 1950-luvulle lähes muuttumattomana pysynyt oppikirjojen kuvaus afrikkalaisista, jonka mukaan "neekerit ovat lapsellisia ja ystävällisiä, mutta samalla valheellisia ja epäluotettavia". Kuvaus on kolonialistinen, "valkoinen" kuvaus Afrikasta. Eri kirjoittajat ovat lainanneet kuvausta omiin oppikirjoihinsa. (Ajagán-Lester 2001: 32-38.) Aavik ja Györffy eivät ole käyttäneet kirjoissaan vastaavaa kuvaustyyliä, vaikka omista asenteista kertova "me ja muut" -asetelma onkin havaittavissa Györffyn 
suomalaisten ruokailutottumuksia kuvaavassa esimerkissä(ks. alaluku 4.2 esimerkki 9).

S2-oppikirjoissa teksteillä havainnollistetaan opetettavaa kielioppiasiaa, mutta ne opettavat myös kulttuuritietoutta, maantuntemusta ja voivat sisältää myös tietoa kohdekielen puhujien ulko- ja sisäpolitiikasta. Näin ne pyrkivät sisällöillään vaikuttamaan opiskelijoiden ajatusmaailmaan. Oppikirjoissa tekstejä käytetään lukemiseen, kysymyksien tekemiseen, niihin vastaamiseen, taustatietona keskustelun virittämiseen sekä vapaaseen keskusteluun ja ajatustenvaihtoon.

\subsection{Aavikin oppikirja}

Olen Lähivõrdlusi. Lähivertailuja 27 -teoksen artikkelissani todennut, että Johannes Aavikilla (1880-1973) oli Helsingin yliopistossa suorittamansa filosofian kandidaatin -tutkinnon ansiosta erinomainen suomen kielen taito. Tutkintoon sisältyneet oppiaineet olivat suomen kieli ja sukukielet, romaaninen filologia, romaaninen kirjallisuus, venäjän kieli ja kirjallisuus. Hän oli myös ansiokas Juhani Ahon tuotannon virontaja sekä viron kielen uudistaja. Viron kieltä uudistaessaan hän lainasi sanoja suomen kielestä ja teki niihin uudistusehdotuksia suomen kielen morfologia esikuvanaan (Vehkanen 2017: 245-249).

Aavikin (1902) Praktilik Soome keele ópetus -kirjan opetussisältö on lähtökohdiltaan kaksikielinen, kauttaaltaan lähtö- ja kohdekieleen tukeutuva. Aavikin (Aavik 1902: V) esipuheessaan mainitsema suomen kielen kiinnostuksen lisääntyminen Virossa antoi toiveita kirjan laajasta lukijakunnasta. Myös kirjan nimessä esiintyvä sana praktilik eli 'käytännön' suomen kielen oppikirja viitannee samaan toiveeseen runsaslukuisesta käyttäjäkunnasta. Kuitenkin kirjoittajan yliopistollinen tausta on nähtävissä kirjan sisällöllisissä valinnoissa. Se vahvistaa käsitystäni siitä, että kirja on tarkoitettu akateemisille suomen kielen harrastajille (Aavik 1902: V). Aavikin oppikirja on väitöskirja-aineistoni ensimmäisiä tasoltaan yliopisto-opetukseen soveltuvia S2-oppikirjoja Unkarissa ja Saksassa julkaistujen teosten ohella (Szinnyei 1916; Neuhaus 1919). 
Se on kielioppikeskeisyydessään lähes kieliopin ja oppikirjan välimuoto. Kirjan sisältö edellyttää opiskelijoilta vieraan kielen filologisia opintoja. Kun kieliopin opetus perustuu viron ja suomen kielen yhtäläisyyksien ja erojen vertailuun (Aavik 1902: 2-10, 63), kirjoittaja näyttää olettavan, että kirjan käyttäjä hallitsee jo ennalta käsin esimerkiksi suomen kielen verbintaivutuksen ja sijamuodot.

Aavikin kirjan kappaleiden alkuosat ovat lähes kontrastiivisen kieliopin kaltaisia: tummennettuihin "laatikkoihin" rajatut kielioppiasiat on saatettu numeroida ja ne saattoivat sisältää opetettavien kielioppiaineksien virolaisia käännöksiä. Kielioppiasiaa seuraava tekstikappale tukee opetettavaa asiaa (esimerkki 1).

(1) $\$ 7$.

Mihin (minne) te menette? - Kuhu te lähete?

Me menemme metsään - Me läheme metsa.

[---]

Küsimise päle kuhu? mille sisse? on ikka kahekordne häälik $+\mathbf{n}$ lõpuks (-aan, -ään, -iin j.n.e.)

[---]

Mihin tämä juna lähtee? - Se tulee Viipurista ja lähte Helsinkiin. Minne te aiotte? - Minä aion Pietariin (Peterburisse). - Mistä (kust) te matkustitte (reisisite) Tarttoon? [---]

(Aavik 1902: 9)

Yllä esimerkkisanat ja -lauseet ovat suomeksi ja suluissa ovat vironkieliset vastaavat käännökset (esimerkki 1). Kirjan tyypillinen formaatti on, että esimerkkilauseet ovat kappaleen alussa. Kieliopilliset selitykset seuraavat sitten viroksi. Kappaleen lopussa on noin puoli sivua kielioppiasiaan liittyviä irrallisia lauseita sisältäviä tekstejä suomeksi, joihin liittyvät sanastot sekä suomeksi että viroksi.

Aavik oli Villem Grünthalin ohella viron kielen merkittävin uudistaja. On ymmärrettävää, että viron kielen sanaston ja uusien kielioppirakenteiden kehittäjänä hän esittää myös oppikirjassaan rinnakkain kieliemme kieliopillisia ratkaisuja ja sanastoa. Viron kielen uudistustyö 1900-luvun alussa sattuu Aavikin oppikirjan ilmestymisajankohdan 
kanssa ajallisesti lähekkäin. (Grünthal 2009: 231, 235-238). Suomen poliittinen tilanne ja autonomian ajan loppuvuodet purkautuvat Aavikin oppikirjan tekstien sisällöissä haluna henkiseen yhteydenpitoon kirjan sisällön kautta. Se näkyy kirjoittajan kansallisromanttisissa ja kaunokirjallisissa tekstivalinnoissa.

\subsection{Aavik ja kansallisromantiikka}

Niin Euroopassa kuin Suomessakin vaikutti 1800-luvun lopulla kansallisromanttinen aatesuuntaus, jonka historiankirjoituksessa ja taiteessa oli isänmaata, luontoa ja kansanrunoutta korostava aatemaailma. Euroopassa pääideologi oli Johann Gottfried von Herder. Ajatusmaailma muuttui kuitenkin voimakkaasti 1900-luvun alussa tekniikan, tieteen ja talouden kehittyessä (Jääskeläinen 1998: 42-43; Peltonen 1998: 26-27; Rojola 1999: 108-111, 114-125; Sulkunen 2004: 26-27). Ensimmäiset aikuisoppikirjat 1900-luvun alussa ovat yliopisto-opettajien kirjoittamia ja sisällöltään vielä kansallisromanttisia. Karjalasta oli tullut Suomessa suomalaisille eräänlainen kulttuurin pyhäkkö, jonne taiteilijat tekivät matkoja. Karelianismi edusti omalla tavallaan menneisyyttä, johon oli hyvä nojautua 1900-luvun alun yhteiskunnallisten ja ideologisten ristiriitojen paineessa: suomalaisen sivistyksen omaleimaisuutta, kaikkea mikä viittasi kansalliseepoksemme, tuli vaalia. (Rojola 1999: 113-114). Johannes Aavik, oman kielensä uudistaja ja suomen kielen ja kirjallisuuden tuntija, pystyi yhdistämään Suomen kansallisen heräämisen oman maansa kansallisen kulttuurin ja kielen uudistamiseen.

Myös Jozséf Szinnyein, Budapestin suomalais-ugrilaisen laitoksen esimiehen, lukukirjan (1916) ja Johannes Neuhausin, Berliinin Friedrich-Wilhelms -yliopiston suomalais-ugrilaisen osaston nykypohjoismaisten kielten lehtorin, oppikirjan (1919) tekstien sisällöt ovat aiheiltaan kansallisromanttisia. Kalevala on suosittu aihe yliopistopiirien oppikirjoissa: Neuhausilla (1919: 36, 70, 99-100) Väinämöisen kantele ja Väinämöisen lähtö sekä Kantelettaresta runo Laula, laula veitoseni, Szinnyeillä (1916: 84-89) Aino, Kalevalan neljäs runo. Sekä Aavikin että 
Neuhausin valitsemissa kansallisromanttisissa teksteissä näkyy Suomen luonnonkauneuden ihailu, samalla kun kansallisuusaate on esillä rohkeasti ja selvästi. Valintaa voi pitää kannanottona Suomen senhetkiseen sortokauden alaiseen poliittiseen tilanteeseen.

Aavikin (1902: 22, 137-140, 143-144) oppikirjan tekstien sisällöt heijastavat myötätuntoa Suomen senhetkistä poliittista tilannetta kohtaan. Maamme poliittista ilmapiiriä hallitsivat 1900-luvun alussa Venäjän keisarikunnan sortotoimet sekä huoli Suomen olemassaolosta kansakuntana ja toisaalta huoli kansallisromanttisen suuntauksen mukaisen idealismin säilyttämisestä (Tapana 2003: 29). Kirjoittaja sijoittaa kirjan alkuun hieman yllätyksellisesti raskaiden kielioppitekstien lomaan Porilaisten marssin ja siihen liittyvän täydellisen sanaston (Aavik 1902: 22). Oppikirjan loppuun on kerätty Suomen senhetkiseen poliittiseen ilmapiiriin liittyviä lauluja: Maamme-laulu, Suomen laulu sekä laulut Herää, Suomi! ja Väinölän lapset. Odotuksenvastaisesti Aavikin (1902: 136-137) teksteissä ei ole mukana runoa Kalevalasta, vaan vain lyhyt selostus Kalevalan kielen piirteistä. Tämä ratkaisu voi toisaalta kertoa myös siitä kirjoittajan käsityksestä, että Kalevala on lukijoille tuttu teos ja että opiskelijat tarvitsivatkin lähinnä vain teoksen kielen piirteiden avaamista. Aavikin lauluvalinnoista voi aistia Suomea ympäröivän maailman ilmestymisajankohdan yhteiskunta- ja kulttuurikontekstin. Virolaiset opiskelijat oppivat tämän tekstilajin ansiosta myös suomen kielioppia. On toki todettava, että lauluja on aina käytetty erilaisten propagandististen tai heimokansallisten aatteiden tarkoitusperien välineenä (Karemaa 1998: 10). Esimerkiksi neuvostoliittolaisen oppikirjantekijä Harald Riihosen (1929: 59-60) laululyriikkaa edustaa oppikirjassa tuon yhteiskunnan senhetkiseen historialliseen tilanteeseen sopivat laulut: Budjonnyin marssi, Neuvostojen puolesta, Punalippu ja Internationale.

Suomen historian silloinen vaihe, kansallinen herääminen ja heimoveljeys, ovat Aavikin teksteissä läsnä. Oppikirjan tekstissä suomalainen maisema näyttäytyy lukijalle vaikuttavana Maamme-laulussa (esimerkki 2). 
(2) Maamme.

Oi maamme, Suomi, synnyinmaa,

Soi, sana kultainen!

Ei laaksoa, ei kukkulaa,

Ei vettä, rantaa rakkaampaa,

Kuin kotimaa tää pohjoinen,

Maa kallis isien!

[--- ]

(Aavik 1902: 137)

Odotuksenmukaisesti Aavikilla Juhani Ahon tuotannon virontajana on oppikirjassaan katkelmia juuri Ahon teoksista, muun muassa Nuoruuden unelma (Katajainen kansa I, 1899) (esimerkki 3), jonka sisältö viittaa Suomen silloiseen historialliseen vaiheeseen.

(3) Nuoruuden unelma (Nooruse unistus)

Jospa tulisivat vielä joskus takaisin ne ihanat ajat, jolloin isänmaan onni kajasti niin kirkkaana ja toivehikkaana edessämme, jolloin sen tulevaisuutta ei johtunut mieleenkään epäillä!

Ei koskaan sen jälkeen, ei edes innostuneimmissa ylioppilasjuhlissakaan ollut varmuus kaikesta niin vankka kuin noina viimeisinä koulupoikavuosinani, tuolla kaukaisessa, pienessä maalaiskaupungissa.

[---]

(Aavik 1902: 53)

Aavikin valitsemassa katkelmassa (esimerkki 3) Juhani Aho kuvaa Suomen muinaisen kulttuurin suuruutta. Esimerkissä koulupojat asettavat suomalaisen muinaiskulttuurin Kreikan vanhaa kulttuuria korkeammalle tasolle: suomalaisilla on miekan tilalla sanan voima. Sanan voimalla kertomuksen pojat aikovat valloittaa maailmaa (Rojola 1999: 114). Aavikin oppikirjan sisältö on pitkälle suomen kielen opinnoissaan edenneille, ehkä juuri yliopisto-opiskelijoille kirjoitettu suomen kielen teos, jonka kansilehdellä Arvi Jänneksen sanoin korostetaan "heimohengen voimalla kansojen lähentymistä”.

Aavikin kirjan tekstinäytteet edustavat eri kaunokirjallisuuden lajeja. Kaunokirjalliset tekstit ovat tekstejä, joista opiskelijan on hyvä 
opiskella suomen kieltä siinä vaiheessa, kun suomen kielioppi on hallinnassa. Maaseutua kuvataan oppikirjojen kaunokirjallisissa tekstinäytteissä. Aavikin (mts. 80-86) oppikirjassa ollaan maaseudulla Juhani Ahon teoksessa Rautatie (esimerkki 4).

(4) [---] Tavallista kiiruummin astuivat Matti ja Liisa, ponnistellen mäkeä ylös. Kuumunut multa jo Liisan jalkapohjia poltteli, ja Matin kantapäätä hankasi kenkä. Päivä hellitteli niskaan sitten melkein kuin keskipäivällä.

- Odotahan nyt, Matti.. elähän nyt semmoista kyytiä.. kun olisi otettu ?hevonen..olisihan se joutanut.

- Mikäs tässä on jalan kävellessä.. tässähän tämä menee, kun on mennyt tähänkin asti. [---]

(Juhani Aho, Rautatie)

(Aavik 1902: 81)

Vaarala (2009: 15) toteaa väitöskirjassaan, että vaikka kirjallisuus ja kieli ovat sidoksissa toisiinsa ja kulkevat rinnan kielenopetuksessa, kielen rakenteiden tarkastelu saattaa jäädä taustalle autenttisissa kaunokirjallisissa näytteissä. Tällöin kaunokirjallisuuden käyttäminen kielenopetuksessa, esimerkiksi erilaisina tekstiesimerkkeinä kielen eri yleis- ja puhekielisistä varieteeteista, edustaakin kielenopetuksessa juuri luonnollista suomen kirjoitettua kieltä tekstien yleis- ja puhekielen variaatioissa.

Runot ja laulut ovat kielipedagogiikan kannalta hyvä tekstilaji, sillä niiden sisältöjen mieleen painamisen avulla opiskelija saattaa muistaa tekstin sanat sävelen ja runopoljennon muodossa paremmin kuin proosatekstin muodossa. Tekstilajia on hyödynnetty kielenopetuksessa kautta aikojen. Sen avulla opiskelija voi muistaa myös kohdekielen kieliopillisesti korrektit muodot laulut ja niiden sanat muistaessaan. Sananlaskut ovat poeettisesti rytmittyneitä, kansanviisauksia ja kansankulttuuriin sisältönsä puolesta liittyviä. Se on harvinainen tekstilaji oppikirjoissa, mutta Aavikin (1902: 29, 34) oppikirjassa niitä kuitenkin esiintyy sanastoineen. Sananlaskuissa käytetty kieli ja typologinen muoto on verrattavissa lyriikan rakenteisiin. Sananlaskut ovat tekstilaji, joka on kerronnaltaan arvoituksellista ja hyvää kielitaitoa vaativaa. 


\subsection{Aavikin muut tekstivalinnat}

Aavikin oppikirja sisältää myös aiheiltaan erilaisia fiktiivisiä ja kirjoittajan itse tuottamia kertomuksia esimerkiksi Suomen luonnosta kuten Matka maantietä myöten kesällä (Aavik 1902: 32) sekä kappaleen, jossa kerrotaan Suomen eri heimoista Suomen asujamisto (Aavik 1902: 40-41). Aavikilla on kirjassaan myös kansainvälisiä aiheita, esimerkiksi tekstejä Sveitsistä, Viipurin merenkäynnistä sekä pitkä, Englannin historian talouselämään ja rahaliikenteeseen liittyvä, ajalle tyypillinen jatkokertomus Greshamin laista (Aavik 1902: 41-42, 68-69, 72-79). Kansainvälinen aihe sisältönsä puolesta on myös Georg Washingtonista kertova teksti Poika, joka tunnusti totuuden (Aavik 1902: 26). Esimerkissä 5 Aavik opettaa sisäpaikallissijoja sekä samalla eri maiden nimien suomenkielisiä kirjoitusasuja.

(5) $\$ 7$

$[---]$

- Minä matkustin rautateitse Tallinnasta Tarttoon ja sielt Riikaan, Riiasta höyrylaivalla

Saksaan (Saksamaale), Saksast Englantiin (Englismaale), Englannista Ranskaan (Frantsusmaale)

ja Italiaan (loe: idaliaan). - Ettekö te halua 'matkustaa' Suomeen? Ikävä kyllä (kahju küll), en.

[---]

(Aavik 1902: 9)

Esimerkissä (5) Aavik kertoo matkailusta, jossa matkataan Virosta naapurimaihin, aina Euroopan sydäntä kohti.

Aavik on lisäksi kirjoittanut kirjaansa fiktiivisiä tekstejä, Ihmeellinen pelastus, Maan synty ja Merimiesjuttu (Aavik 1902: 45, 64, 68), joita sisällöllisesti voisi ehkä pitää kerronnaltaan jonkinlaisina aikuislukijoille mieluisina kertomuksina. Kirjan lopussa on Minervan kirjakaupan luettelo Suomen ja maailman eri alojen suomenkielisestä kirjallisuudesta: luonnontieteen, maantieteen, historian ja taloustieteen alalta (Aavik 1902: 147-149). 
Aavikin kirjan tekstien sisällöt kertovat kirjoittajan Suomessa viettämien opiskeluvuosien aikana hankitusta Suomen maantuntemuksesta, jonka perusteella hänen on helppo ymmärtää myös maan senhetkisen vaikean poliittisen tilanteen vakavuus. Hienovaraisesti ja taidokkaasti myötäeläminen välittyy valinnoista: esimerkkeinä Juhani Ahon tekstikatkelmat, Suomelle tärkeät laulut sekä jo heti oppikirjan kannessa olevat Arvid Jänneksen sanat (vrt. edellä).

\section{Györffyn oppikirja}

Béla Györffy (1892-1951) oli luterilainen pappi ja kansanvalistaja. Hän oli opiskellut myös lääketiedettä ja toimi tässä ominaisuudessa Unkarin maaseudulla niin kutsuttuna kylätohtorina (Béla Györffyn henkilötiedot). Györffy kirjoitti Gyakorlati Finn Nyelvkönyv (1939) -oppikirjansa Unkarin luterilaisille teologian opiskelijoille. Hänellä ei ilmeisesti ollut suomen kielen yliopisto-opiskelutaustaa. Sen seikan ei kuitenkaan tarvinnut olla este oppikirjan laadintaan, sillä juuri papit ovat historian saatossa olleet niin Suomessa kuin muuallakin kansojensa valistajia ja oppikirjojen kirjoittajia (Vehkanen 2015: 37-38). Se, missä ja miten Györffy oli oppinut suomen kielen, on jäänyt toistaiseksi epäselväksi.

Unkarissa kiinnostus suomen sukulaiskieltä kohtaan oli voimakasta jo 1800-luvulla. Tuolloin ilmestyi runsaasti suomen ja unkarin kieltä koskevia teoksia, muun muassa unkarin ja suomen kielen vertailevia esityksiä (Kállay 1844; Hunfalvy 1853), suomenkielisiä lukemistoja unkarilaisille (Hunfalvy 1861; Budenz 1873; Szinnyei 1895) sekä unkarinkielisiä kielioppeja (Fabián 1859; Budenz 1873). Suomella oli Unkarissa myös merkittäviä kielisukulaisuuden vaalijoita 1900-luvun taitteessa, esimerkiksi Budapestin yliopiston suomalais-ugrilaisen laitoksen esimies ja Unkarin tiedeakatemian jäsen József Szinnyei (18931931) sekä saman laitoksen aikaisempi esimies, professori József Budenz (1872-1893). Molemmat tiedemiehet olivat vierailleet Suomessa ja kirjoittaneet runsaasti suomen kieleen liittyviä teoksia. (Karlsson 2000: 70-71; Heikkinen 1981.) 
Györffyn kirja ei kuvauksessaan nojaa kielisukulaisuuteen, kun taas tässä artikkelissa toisena tarkasteltu Aavikin kirja nojaa. Györffyn kirja poikkeaa uskonnollisten aiheidensa puolesta myös Szinnyein ja Budenzin tuotannosta sekä muistakin aikalaisten S2-oppikirjoista.

Kirjansa esipuheessa Györffy (mts. esipuhe) kyllä myös houkuttelee opiskelijoita opiskelemaan suomea kielisukulaisuuden, kielen mielenkiintoisuuden ja sukulaiskansan elämään tutustumisen vuoksi. Oppikirja oli teologian opiskelijoiden suomen kielen kurssikirja, joka sisältää runsaasti Raamatun kappaleita, rukouksia ja uskonnollisten henkilöiden elämänkertoja. Esipuheen sisällöstä saa toisaalta sellaisen vaikutelman, että kirjoittaja olisi pyrkinyt houkuttelemaan pappisoppilaiden ohella myös muita suomen kielestä kiinnostuneita aloittamaan opinnot oppikirjansa avulla.

Kuten yllä totean Györffy kirjan sisältö ei kuvauksessaan nojaa kielten väliseen vertailuun eikä kielisukulaisuuteen kuten Aavikin kirja, vaan Györffy (1939: 8-18) noudattelee kieliopin esityksessään Aavikin tavasta poikkeavia sisällöllisiä ratkaisuja. Kirjoittaja aloittaa olla-verbin taivutuksella, jonka jälkeen kerrotaan nominatiivin yksikkö- ja monikkomuodot: talo, 'ház'; talot, 'házak'. Kielen morfologian peruspiirteet opetetaan toinen toisensa jälkeen kirjoittajan harkitsemassa järjestyksessä Aavikin lähtö- ja kohdekielien vertailua sisältävästä kuvaustavasta poiketen. Kieliopin kuvauksen järjestys muistuttaa paljon muita saman aikakauden suomea vieraana kielenä -oppikirjojen kuvauksia (vrt. Neuvonen 1935; Bergh 1940) ja jopa tämän päivän S2-oppikirjan esittämisjärjestystä (Pesonen \& Vehkanen 2016).

Györffyn (1939: 19-20) kirjassa kielioppiasia esimerkkeineen on kappaleen alussa, sitten tulevat unkarinkielinen kielioppiasia esimerkein, suomenkielinen lukukappale, unkarinkielinen keskustelukappale, siihen liittyvä suomi-unkari-sanasto ja lopuksi vielä unkarinkielinen "Huomautuksia"-kappale, jossa selitetään uudelleen kappaleessa esitettyä kieliopin piirrettä unkariksi. Kirjoittaja esittää toisinaan kappaleissaan opiskelijalle kysymyksiä, joihin opettaja odottaa oppilaan itse tuottamia vastauksia. Oppikirjan sisällön järjestys pysyy samana läpi 
kirjan. Sisällön punaisena lankana on kieliopin opetus, ja kappaleet sisältävät myös säännöllisesti käännöksiä unkarista suomeen ja päinvastoin. Kirja on toisaalta hyvä esimerkki kielioppi-käännösmenetelmää noudattavasta oppikirjasta, mutta opiskelijoille esitetyt kysymykset ja opiskelijan itse niihin tuottamat vastaukset ovat jo viitteitä kommunikatiivisesta opetusmenetelmästä.

\subsection{Györffy ja uskonnolliset tekstit}

Györffyn runsaasti uskonnollista kerrontaa sisältävä aihevalinta olisi saattanut olla käyttökelpoinen sata vuotta aikaisemmin Pohjoismaissakin, jolloin oppikirjakirjallisuutta oli vähän ja se oli tavallisesti uskonnollista kirjallisuutta tai sen sävyttämää (Vehkanen 2015: 170-171). Oppikirjan asema oli 1900-luvun alkupuolella kuitenkin jo toinen. Eri maiden yhteydet Eurooppaan lisääntyivät ja kaupunkikulttuurin ihannointi olivat jo tosiasioita (Laine 2002: 102-111; Salokangas 2003: 678-679, 685-686; Ekvall 2001: 57). Syy tekstien uskonnollissävytteisyyteen on selvä. Kirjoittajan aiheiden valintaan vaikuttaa hänen henkilökohtainen papillinen taustansa sekä kirjan käyttäjien pääkohderyhmä. Kirjoittajan erityistehtävänä oli tuottaa Unkarin luterilaisille, teologiaa opiskeleville pappisopiskelijoille oppikirja. Kirjan sisällön tuli olla sopivan uskonnollissävytteinen ja samalla pätevä oppikirja suomen kielen ja Suomen kulttuurin opetukseen.

Erityisen runsaasti uskonnollista kerrontaa on kappaleessa Olvasmányok, Lukemisto (Györffy 1939: 138-141, 158-168), jossa on lukuisia katkelmia Raamatusta, Suomen herätysliikkeistä sekä luterilaisen kirkon merkkihenkilöiden elämäkerroista (Györffy 1939: 15, 32, 50-51, $65,90,102,104)$. Oppikirjan taustan ja tekstien sisällön ymmärtämisen kannalta keskeinen osio on kappale Unkarin ja Suomen luterilaisten kirkkojen yhteys (Györffy 1939: 166-169). Se kertoo Suomen ja Unkarin luterilaisten kirkkojen välisestä yhteydestä 1900-luvun alussa. Oppikirjan artikkelin kirjoittaja K. E. Rinne pitää yhteyksien luojana Suomessa kouluneuvos Matti Pesosta, jonka pojan hän mainitsee taistelleen Viron 
vapaussodassa. Tässä yhteydessä mainitaan veljesrakkaus ja Pesosen kerrotaan ensimmäisenä ehdottaneen suomalais-ugrilaisten kulttuurikongressien järjestämistä, joita sitten alettiinkin järjestää. Unkarissa vastaaviin Suomen ja Unkarin välisiin uskonnollisiin suhteisiin vaikutti professori Paavo Podmaniczky. Suomalaisten ja unkarilaisten teologian opiskelijoiden vaihto alkoi maiden välillä vuonna 1927. Kirjan ilmestymisen aikoihin 1939 Suomessa oli opiskellut 13 unkarilaista nuorta pappia ja Unkarissa vastaavasti 10 suomalaista pappisopiskelijaa. Tätä taustaa vasten Györffyn oppikirja oli opiskelijoille epäilemättä tarpeellinen ja hyödyllinen. Kappaleen kirjoittaja kertoo myös, että Unkarissa järjestettiin kirjan ilmestymisen aikoihin suomalais-ugrilainen pappeinkokous ja että seuraava kokous oli suunnitteilla Suomeen vuonna 1941, “jos Jumala suo". Tähän kokoukseen olisi osallistumassa myös virolaisia teologeja Rinteen tietojen mukaan (Györffy 1939: 166-168). Kappale päättyy Matti Pesosen kirjoittamaan kalevalaiseen heimohymniehdotukseen (Györffy 1939: 169):

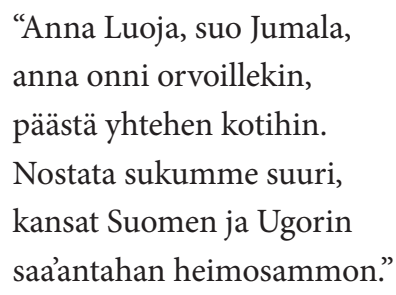

Suomalaiset ja unkarilaiset pappisoppilaat opiskelivat toistensa kieliä maiden välisten teologisten yhteyksien kannustamina. Vaikka ympäröivän maailman rauhattomat ajat tulevat Rinteen artikkelissa esiin, siinä ei ole suoria viitteitä Suomen sotatilasta. Kirja on mahdollisesti kirjoitettu aikaisemmin ja saatu valmiiksi ja painettu vuonna 1939, ehkä ennen Suomen talvisotaa. Kuitenkin levoton, historiallinen tilanne oli aistittavissa artikkelin sisällöstä, ehkä myös omana, hiljaisena kannustimena yhteistyölle. Myös Györffyn oppikirjan sisältämät suomalaiselle merkitykselliset Porilaisten marssi ja Maamme, saavat Rinteen kirjoitukseen tutustumisen jälkeen uuden, heimokansallisen merkityksen. 
Györffyn oppikirjan eri teksteissä Raamatun kappaleiden katkelmat ja rukoukset (ks. esimerkit 6,7) kertovat kirjoittajan kristillisestä näkemyksestä. Myös oppikirjan kohderyhmä on todennäköisesti vaikuttanut valintoihin.

(6) Olvasmány. (Lukukappale.)

[---]

Jeesus ravitsee viisituhatta miestä.

(Matteuksen evankeliumin 14. luku)

13. Kun Jeesus sen kuuli, lähti hän sieltä venheellä autioon paikkaan, yksinäisyyteen. Ja tämän kuultuaan kansa meni jalkaisin kaupungeista hänen jälkeensä.

14. Ja astuessaan maihin Jeesus näki paljon kansaa, ja hänen kävi heitä sääliksi, ja hän paransi heidän sairaansa.

$[---]$

(Györffy 1939: 65)

(7) Olvasmány. (Lukukappale.)

Herran rukous.

Isä meidän, joka olet taivaissa!

Pyhitetty olkoon sinun nimesi;

tulkoon sinun valtakuntasi; [---]

(Györffy 1939: 50-51)

Rukous on harvinainen oppikirjan tekstilaji, mutta tässä oppikirjassa luonnollinen valinta oppikirjan tekijältä. Rukous saattaa olla laulujen ja runojen tapaan sisältönsä puolesta hyödyllinen kirjaa käyttäville pappisopiskelijoille. Kun tulee Suomeen kirkon vieraaksi, on hyvä tuntea tekstejä ennestään. Vieras osallistuu varmasti usein jumalanpalveluksiin ja muihin seurakunnan tilaisuuksiin ja tunnistaa näissä jo esimerkiksi yllä olevan rukouksen. Lisäksi rukouksen avulla opiskelija myös ehkä muistaa kohdekielen kieliopillisesti korrektit muodot rukouksen lauseet opittuaan.

Györffyn (1939: 131-132) oppikirjassa on yllätyksellisesti myös malli kauppakirjeestä. Tässä kirjeessä tilataan muun muassa kristillistä kirjallisuutta (esimerkki 8). 
(8) Olvasmány. (Lukukappale.)

Kauppakirje.

Győrissä 15 p:nä huhtikuuta 1939.

Nuorten Naisten Kristillisen Yhdistyksen Kirjakauppa

$\mathrm{H}$ e $\mathrm{l}$ s in $\mathrm{ki}$.

Pyydän kunnioittaen tilata seuraavat teokset:

2 kpl. E.W. Pakkala: Herra sen tekee, saarnakokoelma, sidottuna.

5 kpl. E.W. Pakkala: Iankaikkinen elämä, sidottuna.

Näiden kirjojen lisäksi pyydän samalla tilata

20 kpl. kultatähkä postikorttia,

2 kpl. kuvakortti Helsingistä.

2 kpl. albumia (Helsinki, Suomi),

$1 \mathrm{kpl}$. Suomen kartta (ei liian suuri).

Pyydän merkitsemään nämä siellä olevalle opiskelijatililleni.

Paketti osoitetaan: Győr. Petöfi-tér 2.

Hannu Pietilä

pastori.

(Györffy 1939: 132)

Esimerkissä (8) oppikirjan kielioppiasiana ovat yhdyssanat. Kirjoittajan laatimassa tekstissä on tekstilaji (Kauppakirje) eksplisiittisesti mainittu, ja siinä on myös kauppakirjeen formaatti: on päiväys, saajan nimi ja osoite, kohteliaisuusfraasi tilauksen alussa, luettelo tilattavista tavaroista, kirjeen lähettäjän tilitiedot sekä hänen osoitteensa, nimensä ja ammattinsa. Esimerkki on selvä kauppakirjeen malli, jota pappisopiskelijat saattoivat käyttää mahdollisessa maiden välisessä kirkollisessa ja seurakunnallisessa kanssakäymisessä.

Györffy näyttäytyy oppikirjassaan ennen kaikkea pappina ja pappisopiskelijoiden uskonnollissävytteisen oppikirjan laatijana. Hänen kirjansa perussävy on uskonnollinen, mutta sen ohella kirjan kappaleet sisältävät runsaasti tietoa Suomesta, suomalaisista ja maan kulttuurista ja suomalais-ugrilaisesta kielisukulaisuudesta (Györffy 1939: 88, 117, $121,123,126,128,130-131,133,135-137)$. Niin kieliopillisen, uskonnollisen kuin maantuntemuksellisenkin sisällön avulla kirjaa käyttävät opiskelijat saivat monipuolisesti tietoa Suomesta ja suomen kielestä. 


\subsection{Maantuntemuksesta}

Eri maiden kuvaukset eivät ole olleet tavallisia S2-oppikirjoissa (ks. Vehkanen 2015). Szinnyein (1916: 55-60) lukemiston Aleksis Kiven näytelmässä Lea ollaan Palestiinassa. Kuvatut kohteet ovat kaukaisia ja omien lähimaiden kriisien ulkopuolella. Bergh (1940: 40-41) kertoo lyhyesti Roomasta ja Viipurista kaupunkielämää kuvaavassa luvussaan, mutta kuvaa muuten kirjansa kertomuksissa Ruotsin historiaa ja kaupunkeja.

Aavikin teksteissä (ks. 3.2) matkustettiin lukuisiin Euroopan maihin. Györffy taas opettaa suomalaista maantuntemusta suomalaisen ruokakulttuurin kuvauksen avulla (esimerkki 9).

(9) Olvasmány. (Lukukappale.)

Suomalaisten ruokailu.

Suomalaisilla on kaksi pääateriaa, aamiainen ja päivällinen. Aamiaiseksi (reggelire) he syövät tavallisesti lihaa perunoiden kanssa ja puuroa (kását). Päivälliseksi (ebédre) he syövät kaksi tai kolme hyvää ruokalajia. Tämän lisäksi on aamukahvi heti ylösnousun jälkeen (felkelés után), ja päiväkahvi keskipäivällä (délben). Illalla he juovat iltateen (esti teát).

Kun suomalaiset syövät, silloin he keskustelevat suomeksi, mutta he osaavat keskustella myös saksaksi ja toivottavasti myös unkariksi. Niin elävät unkarilaisten sukulaiset.

(Györffy 1939: 23-24)

Esimerkki (9) on otsikoitu aiheen mukaan. Sen sisältö vaikuttaa lähinnä luettelolta suomalaisista ruokailutavoista ja -tottumuksista Suomeen aikoville matkailijoille. Tekstin kielioppiasia on translatiivi, ja unkarinkieliset käännökset sulkeissa saattavat helpottaa unkarilaista opiskelijaa eri aterioiden nimien mieleen painamisessa. Tämä ruokailuteksti, jossa kirjoittaja kertoo maanmiehilleen Suomen ruokailutavoista, on tosin otteeltaan etäinen. Siitä voi aistia "me ja muut" -asenteen Ajagán-Lesterin (2001: 32-38) tulkitsemalla tavalla: kirjoittaja kuvailee suomalaisia ruokatottumuksia omasta kulttuuristaan ja omista asenteistaan käsin. Esimerkin 9 kuvaus tuskin vastaa suomalaisten todellisia 
ruokailutottumuksia 1930-luvulla, vaan perustunee pikemminkin kirjoittajan näkemykseen ja käsityksiin suomalaisten ruokailutavoista (vrt. Karemaa 1998: 10). Toisaalla kirjassaan Györffy kuvaa maantuntemusta fiktiivisellä tarinalla maaseudulta, työskentelystä pellolla (esimerkki 10).

(10) Olvasmány. (Lukukappale.)

Elonleikkuussa.

Eilen aamulla sanoi isä, että iltapäivällä menemme pellolle.

Seisoimme ruispellon pientareella ja isä koetteli tähkäpäitä.

Sitten kiipesimme vähän ylöspäin ja istuuduimme kivelle. Kultaisena lainehti edessämme kypsyvä vilja. Isä risti kätensä.

Hän oli vakavan näköinen. „Jumala on antanut meille hyvän sadon.

Saamme leipää talveksi”, hän sanoi.

Koko päivän olemme nyt olleet pellolla.

Äiti ja sisareni ovat tuoneet kahvia ja ruokaa pellolle.

Päivä on kulunut hupaisesti.

(Györffy 1939: 78.)

Maaseutukuvauksia on niukasti 1900-luvun alkupuolen aikuisten S2-oppikirjoissa (ks. Vehkanen 2015). Györffyn (1939: 78) lisäksi niitä esiintyy B. G. Geijerin ja Kaarlo Niemisen (1940: 91-93) oppikirjan sota-ajan ruotsinkieliselle siviiliväestölle suunnatuissa dialogeissa sekä Emil Nestor Setälän ja Vilho Setälän (1934: 44-45) puhetta opettavan fraasikirjan maaseutua käsittelevässä kappaleessa. Tekstit sisälsivät jo tuolloin enemmän kaupunkilaistumiseen ja turismiin liittyviä tarinoita.

Kaupunkikuvaukset alkoivat hallita S2-oppikirjojen sisältöjä ensimmäisen maailmansodan jälkeen kansainvälistymisinnostuksen huumassa. Kun teollistuminen oli päässyt vauhtiin Suomessa, ihmiset siirtyivät maalta kaupunkiin ansiotyön perässä (Virrankoski 2012: 349-351). Yhteiskunnallinen muutos näkyy myös S2-oppikirjojen sisältöjen kaupunkilaiskuvauksissa. Helsinki on kuvatuin kaupunki. Siitä kerrotaan oppikirjoissa (mm. Tuomikoski \& Deans 1952: 20) asiallisesti asukasluku ja perustamisvuosi mainiten, mutta niiden lisäksi kerrotaan yleensä jotakin muutakin. Seuraavissa esimerkeissä (esim. 11 Györffy 1939: 145; esim. 12 Neuvonen 1935: 20) Helsingistä kerrotaan sekä 
historiallisia että lukumääräisiä tietoja, mutta myös myönteisiä yksityiskohtia kaupungin olemuksesta ja sijainnista.

(11) Helsinki; „Pohjolan valkea kaupunki!”

Helsinki on Suomen suurin kaupunki (yli 300.000 asukasta) ja maailman pohjoisin pääkaupunki.

Mutta paitsi ilman kirkkautta ja valoisia öitä ei kesäisessä Helsingissä mikään viittaa sen pohjoiseen asemaan.

Jykevä rakennustyyli voi ehkä antaa siitä aavistuksen, mutta kukoistavat puistot ja istutukset, värikkäät

ulkoilmaravintolat, valkoiset purjeet lähiulapoilla - kaikki nämä ovat ilmeisiä kesän tuntomerkkejä. [---]

$[---]$

(Györffy 1939: 145)

\section{(12) HELSINKI}

[---]

Helsinki on verrattain nuori kaupunki, se on perustettu vuonna 1550, vähän pohjoiseen nykyisestä paikastaan, Vantaanjoen suulle. 1640 se siirrettiin suunnilleen siihen, missä se on nytkin. Vasta vuonna 1812 Helsingistä tehtiin pääkaupunki.

[---]

Helsinki on uudenaikaisesti rakennettu, puhdas ja rauhallinen, ja varsinkin meren puolelta katsottuna se on kaunis nähdä. Turhaan ei sitä sanota Pohjolan valkeaksi kaupungiksi».

(Neuvonen 1935: 20)

Kun Györffyn (mts. 46) oppikirjan kappaleessa opetetaan ulko- ja sisäpaikallissijoja, on sisällöksi valittukin Unkarin maantuntemusta ja kulttuuritietoutta sisältävä kirje, jota seuraa vastaus - ensin suomeksi ja sitten unkariksi (esimerkki 13).

(13) Olvasmány. (Lukukappale.)

Hyvä veljeni!

Viikon alussa olimme vielä yhdessä sukutilallamme Suomessa, ja jo eilen saavuin Unkarin kauniiseen pääkaupunkiin (-ba).

Budapest on juhla-asussa. Kaikkialla on kukkia ja valoja. 
SUOMI VIERAANA KIELENÄ - OPPIKIRJOJEN SISÄLTÖJEN SUHDE OMAN AIKANSA ILMIÖIHIN

Talojen katoilta ja ikkunoista riippuu (lengenek) puna-valko-vihreitä lippuja. Unkari juhlii Pohjois-Unkarin palaamista (hazatérését).

Unkarilaisilta ystävältäni olen kuullut paljon suurista juhlista.

Nyt minäkin iloitsen heidän kanssaan. Paljon terveisiä

Pekka.

Feladat. (Tehtävä.)

Kedves testvérem!

Már minden nap váruk leveledet (part.). Tegnap vérge egy lapot kaptunk (saimme) tőled (sinulta).

Mi is örülünk, hogy szerencsésen megérkeztél szép Magyarországra.

Magyar testvéreinkkel együtt (kanssa) örültunk mi is ezekben (näinä) a történelmi napokban (ess.).

Istentől a jövőben is áldást kérünk Magyarországra (-1le).

Köszönjük barátaid üdvözletét (elat.).

Tőlem is, szüleinktől is sok üdvözlet!

Növéred Ágnes

Hyvä Veli!

(tuntemattoman tekijän käännös)

Olen odottanut kirjettäsi joka päivä. Eilen lopultakin sain sinulta kirjeen.

Mekin iloitsemme, että pääsitte onnellisesti perille kauniiseen Unkariin. Unkarilaisten veljiemme kanssa iloitsemme yhdessä siitä näinä historiallisina aikoina.

Jumalalta pyydämme siunausta myös tulevaisuudessa Unkarille.

Kiitämme ystäviesi terveisistä.

Sekä minulta että vanhemmiltani paljon terveisiä!

Sisaresi Ágnes

Kirje on melko harvinainen tekstilaji S2-oppikirjoissa, mutta niitä on kuitenkin esiintynyt uudemmissakin unkarinkielisissä S2-oppikirjoissa (esim. Karanko ym. 1990: 182-183). Kirje kannustaa uutta kieltä opiskelevaa opiskelijaa tarttumaan kynään ja kirjoittamaan kirjeen kohdekieliselle henkilölle. 


\subsection{Kansallisromantiikkaa, satuja ja matkailufraaseja}

Györffy (1939: 141-144) opettaa suomea käytännöllisesti, ja hän tutustuttaa opiskelijat pragmaattisesti suomalaiseen kulttuuriin oppikirjansa luvussa Suomen maa ja kansa. Tähän lukuun hän on sisällyttänyt Maamme-laulun sekä perehdyttänyt opiskelijat suomalaiseen kulttuuriin Johan Ludvig Runebergin ja Zacharias Topeliuksen tuotannon tekstikatkelmien avulla. Kalevalan runo on kirjan lopussa sananselityksillä täydennettynä (Györffy 1939: 169).

Satujen käyttö 1900-luvun aikuisten S2-oppikirjoissa on melko harvinaista. Jos niitä kirjoissa esiintyy, ne ovat usein aiheiltaan samankaltaisia ja ne on sijoitettu aikuisten oppikirjojen toisten osien alkuun, ikään kuin "helppoina teksteinä", vaikka ne eivät sitä kieliopillisesti olekaan. Neuhausin (1919: 22) oppikirjassa on eläinsatu Susi ja vaimo. Kuitenkin Szinnyeillä (1916: 16-27, 30-43) on lukukirjassaan poikkeuksellisen paljon satuja. Niiden aihepiireinä ovat suomalaiset kansansadut tai kaunokirjallisuudesta lainatut eeppiset katkelmat, jotka sisältävät paljon dialogeja: Karhu ja mies (kansansatu), Haastelevat kuuset (kansansatu), Ihmeelliset sepät (kansansatu) ja Leikkisatuja (Z. Topelius). Kirjan ilmestymisaikaan ne saattoivat tuntua luonnollisilta valinnoilta ja lukukirjan aiheiksi sopivilta. Syynä lienee se, että suomenkielisiä, oppikirjaan soveltuvia tekstejä ei siihen aikaan ollut liiemmälti saatavilla. Sadut ovat kertovaa, juonellista kertomakirjallisuutta ja lukukirjaan sopivaa epäpoliittista luettavaa.

Györffynkin teksteissä esiintyy muutamia satuja: Ketun taikasauva (Györffy 1939: 29), Hiiri räätälinä (Györffy 1939: 40-41), Hölmöläisten tupa (Györffy 1939: 55-56) ja Hölmöläiset metsästämässä (Györffy 1939: 125). Sadut 1930-luvun lopussa julkaistussa S2-oppikirjassa on erikoinen ja ilmestymisajankohtaan nähden jo harvinainen sisällöllinen ratkaisu. Ne vaikuttavat uskonnollissävytteisten tekstiensä lomassa sisällöllisesti irrallisilta.

Györffyn (Györffy 1939: 170-171) kirjan lopussa on lyhyt fraasiosuus, jonka tarkoitus on jakaa oppikirjan sisältöä laajemmallekin yleisölle Suomeen kohdistuvan matkailun tarpeisiin (esimerkki 14). 
(14) III. RÉSZ.

Uti-kalauz.

Asemalla - állomáson.

Saisinko matkalipun Helsinkiin, Kérek jegyet Helsinkibe

kolmannessa luokassa. a harmadik osztályra.

Paljonko se maksaa? Mennyibe kerül?

Onko tässä junassa makuuvaunua? Van-e ezen a vonaton hálókocsi?

Milloin juna lähtee? Mikor indul a vonat?

Viiden minuutin kuluttua. Öt perc múlva.

[---]

(Györffy 1939: 170)

Matkailukappaleella Györffy valmistaa opiskelijansa tuleviin opiskelijavaihtomatkoihin Suomeen, samoin kuin muut kirjan opiskelijat Suomeen suuntautuviin turistimatkoihin.

Györffyn oppikirjalla on luterilaisten pappisoppilaiden oppikirjana erityistehtävä. Kirjoittaja onnistuu tehtävässään toivotulla tavalla: suomen kielen keskeiset piirteet sekä Suomen maantuntemusta ja kulttuuria opetetaan tekstivalintojen avulla kirjassa riittävästi sen pääsanomaa eli luterilaista uskontoa unohtamatta. Oppikirjan kappale Unkarin ja Suomen luterilaisten kirkkojen yhteys (Györffy 1939: 166-169) kuvaa Unkarin ja Suomen luterilaisten kirkkojen yhteistyötä sekä syventää käsitystä suomalais-ugrilaisten kielten sukulaisuudesta ja kansojen heimoyhteydestä.

\section{Yhteenveto}

Tutkimani perusteella molemmissa oppikirjoissa on runsaasti yhteisiä tekstien aihepiirejä. Tavanomaisen S2-oppikirjan sisältöjen kaltaisia asioita opetettiin myös näissä oppikirjoissa: Suomen maantuntemusta, kulttuuria, kirjallisuutta, eri maiden historiaa, luontoa ja matkailua. Myös kieliopin keskeisyys teksteissä on molemmissa kirjoissa ilmeinen. Sisällöissä on kuitenkin myös selviä eroja. Aavikilla kansallisromanttiset aihepiirit ovat monella tavalla teksteissä esillä, Györffyllä sisältöjä 
hallitsevat taas selvästi kirjoittajan luterilaiseen uskontoon liittyvä ajatusmaailma ja siihen liittyvät aiheet. Näkyvä ero on niin ikään Aavikin tekstien suomen ja viron kielten vertaileva ote; vastaava lähtö- ja kohdekielen vertailu Györffyn teksteistä puuttuu. Molempien kirjojen käyttötarkoitukset säätelevät näin kirjojen sisältöjä. Kirjoittajien esipuheissaan lausuma toive siitä, että oppikirjat tavoittaisivat laajemmankin lukijapiirin kuin varsinaiset kohderyhmät - Aavikin opinnoissaan pitkälle edistyneet suomen kielen opiskelijat, Györffyn luterilaiset pappisopiskelijat - ei käsitykseni mukaan toteutunut. Aavikilla esteenä on sisällön akateemisen filologinen ote, Györffyllä uskonnolliset tekstit, jotka saattoivat vähentää tavallisen kielenopiskelijan mielenkiintoa kirjaa kohtaan (Vehkanen 2015: 48-50).

Entä näkyykö kirjoissa molempien ajankohtien historiallinen todellisuus? Näkyy kyllä. Aavik yliopistossakin opettaneena filologina ja suomen kielen sekä Suomen kulttuurin ja maan syvällisenä tuntijana osasi hienovaraisesti tuoda esiin huolensa Suomeen kohdistuneista senhetkisistä sortotoimista Venäjän suuriruhtinaskunnan alaisuudessa kaunokirjallisissa katkelmissaan ja kirjaan sisällytetyissä suomalaisissa lauluissa. Hän kätki huolensa rivien väliin, ei ollut provokatiivinen, mutta oli samalla tehokas siinä, mihin hän tekstikatkelmiansa sijoitti. Selkeimmin hän tuo ajatusmaailmansa esille kannen Arvid Jänneksen sanoissa heimohengen voimasta edistämässä kansojen lähentymistä.

Györffyn oppikirjalla on oma erityistehtävänsä luterilaisten pappisoppilaiden oppikirjana. Kirja vaikuttaa ensi silmäyksellä kieltä, maantuntemusta, kaunokirjallisia katkelmia ja kulttuuria sisältävältä tyypilliseltä epäpoliittiselta S2-oppikirjalta, jonka teksteissä on lisäksi runsas uskonnollinen sisältö, mutta kun lukija tutustuu oppikirjan loppupuolen kappaleeseen Unkarin ja Suomen luterilaisten kirkkojen yhteys (Györffy 1939: 166-169), lukijan näkemys kirjasta muuttuu. Kappaleessa avautuu lämminhenkinen kuvaus Unkarin ja Suomen luterilaisten kirkkojen yhteistyöstä, oppikirjan suomalais-ugrilaisten kielten heimokansallisesta yhteydestä sekä kirjoittajan huolesta, joka liittyy maailman senhetkiseen poliittiseen tilanteeseen. Molempien kirjojen 
teksteissä näkyy siis ilmestymisajankohdan ja tekstien valinnan yhteisvaikutus: kaiken tavanomaisen kielenopetuksen lomassa kirjan käyttäjät tulevat osallisiksi kirjoittajien hienovaraisista ajatuksista senhetkisestä ympäröivästä yhteiskunnasta ja poliittisista jännitteistä. Huomioon on otettava, että oppikirja kirjoitetaan aina tietyssä yhteiskunnallisessa kontekstissa.

\section{Kiitokset}

Kiitän tekstini kahta anonyymia arvioijaa.

\section{Tutkimusaineiston oppikirjat}

Aavik, Johannes 1902. Praktilik Soome keele õpetus. Helsingis: Yrjö Weilin'in kirjastus.

Györffy Béla 1939. Gyakorlati Finn Nyelvkönyv. Győr: Harangszó Kiadása.

\section{Lähteet}

Aho, Juhani 1899. Katajainen kansani ja muita uusia ja vanhoja lastuja vuosilta 1891 ja 1899. Porvoo: Werner Söderström.

Ajagán-Lester, Luis 2001. Bilden av "de andra". Afrikaner i svenska skoltexter 1768-1920. - Björn Melander, Björn Olsson (Red.), Verklighetens texter. Lund: Studentlitteratur, 25-42.

Béla Györffyn henkilötiedot. http://www.freeweb.hu/felpec2/hnagygyor.php (24.10.2015).

Bergh, Volmar 1940. Finsk Språklära. Grammatik med text och ordförteckning jämte ö versättningsövningar. Stockholm: C. E. Fritzes Bokförlags Aktiebolag.

Budenz, József 1873. Rövid Finn Nyelvtan (alaktan) és olvasmányok. Budapest: Kókai Lajos Kiadása.

Ekvall, Ulla 2001. Den styrda och styrande läroboken. - Björn Melander, Björn Olsson (Red.), Verklighetens texter. Lund: Studentlitteratur, 43-77.

Elomaa, Eeva 2009. Oppikirja eläköön! Teoreettisia ja käytännön näkökohtia kielten oppimateriaalien uudistamiseen. Jyväskylä Studies in Humanities 122. Jyväskylä: Jyväskylän yliopisto.

Fábián, István 1859. Finn nyelvtan. Pest: Emich Gusztáv nyomtatása. 
Geijer, B. G., Kaarlo Nieminen 1940. Snabbkurs i Finska. Kort handledning i finska språket av B. G. Geijer, Lärare vid Kungl. Krigshögskolan jämte Kortfattad svensk-finsk parlör av Kaarlo Nieminen Lektor i finska språket vid Helsingfors universitet. Stockholm: Svenska Bokförlaget. P. A. Norstedt \& Söner.

Grünthal, Riho 2009. Suomen kielen vaikutus viron kieleen. - Jyrki Kalliokoski, Lari Kotilainen, Päivi Pahta (Toim.), Kielet kohtaavat. Tietolipas 227. Helsinki: Suomalainen Kirjallisuuden Seura, 231-260.

Heikkinen, Liisa 1981. Suomenkielisen suomen kielen oppikirjan synty ja kehittyminen 1880-luvulla. Folia Fennistica \& Linguistica. Tampereen yliopiston suomen kielen ja yleisen kielitieteen laitoksen julkaisuja 4. Tampere: Tampereen yliopisto.

Heikkinen, Vesa, Eero Voutilainen 2012. Genre - monitieteinen näkökulma. Vesa Heikkinen, Eero Voutilainen, Petri Lauerma, Ulla Tiililä, Mikko Lounela (Toim.), Genreanalyysi - tekstilajitutkimuksen käsikirja. Helsinki: Gaudeamus, 17-47.

Hiidenmaa, Pirjo 2003. Suomen kieli - who cares? Keuruu: Otava.

Hirsjärvi, Sirkka, Pirkko Remes, Paula Sajavaara 2013. Tutki ja kirjoita. 18. painos. Helsinki: Tammi.

Hunfalvy, Pál 1853. Finn és magyar szók. Pest: Egybehasonlitása.

Hunfalvy, Pál 1861. Finn olvasmányok. A finn nyelvet tanulók számára. Pest: Eggenberger Ferdinánd akademiai.

Jääskeläinen, Ari 1998. Kansallistava kansanrunous. Suomalaisuus ja folklore. Pertti Alasuutari, Petri Ruuska (Toim.), Elävänä Euroopassa. Muuttuva suomalainen identiteetti. Tampere: Vastapaino, 41-82.

Karlsson, Fred 2000. E. N. Setälä vaarallisilla vesillä. Tieteellisen vallankäytön, käyttäytymisen ja perinteen analyysi. SKS:n toimituksia 765. Helsinki: Suomalainen Kirjallisuuden Seura.

Kállay, Ferencz 1844. Finn-magyar nyelv. Pesten: Landerer és Heckenastnál.

Kalliokoski, Jyrki 2002. Tekstilajin taju. - Ilona Herlin, Jyrki Kalliokoski, Lari Kotilainen, Tiina Onikki-Rantajääskö (Toim.), Äidinkielen merkitykset. SKS:n toimituksia 869. Helsinki: Suomalainen Kirjallisuuden Seura, 147-159.

Karanko, Outi, László Keresztes, Irmeli Kniivilä 1990. Finn nyelvkönyv haladóknak. Budapest: Tankönykiadó.

Karemaa, Outi 1998. Vihollisia, vainoojia, syöpäläisiä. Venäläisviha Suomessa 1917-1923. Bibliotheca historica 30. Helsinki: Suomen Historiallinen Seura. 
Karvonen, Pirjo 1995. Oppikirjateksti toimintana. SKS:n toimituksia 632. Helsinki: Suomalainen Kirjallisuuden Seura.

Korhonen, Seija 2012. Oppijan suomi. Koulutettujen aikuisten käsitykset ja kompetenssit. Kielikeskuksen julkaisuja 3. Helsinki: Unigrafia Oy.

Laine, Tuija 2002. Kirkossa, kaupungissa, kolhoosissa. Suomalaisten aapisten arvoista Agricolasta 1960-luvulle. - Inkeri Pitkäranta (Toim.), ABC Lukeminen esivallan palveluksessa. Kansalliskirjaston Gallerian julkaisuja nro 2. Helsinki: Helsingin yliopiston kirjasto, 79-132.

Långström, Sture 1997. Författarröst och lärobokstradition. En historiedidaktisk studie. Institutionen för svenska \& samhällsvetenskapliga ämnen. Umeå: Umeå universitet.

Melander, Björn, Björn Olsson (Red.) 2001. VErklighetens texter. Sjutton fallstudier. Lund: Studentlitteratur.

Mäntynen, Anne 2003. Miten kielestä kerrotaan. Kielijuttujen retoriikkaa. SKS:n toimituksia 926. Helsinki: Suomalainen Kirjallisuuden Seura.

Neuhaus, Johannes 1919. Kleine finnische Sprachlehre nebst einem Wörterverzeichnis der finnisch-indoeuropäischen Entlehnungen von Johannes Neuhaus, Lektor des Neunordischen an der Universität Berlin. Zweite Aufgabe. Heidelberg: Julius Groos Verlag.

Neuvonen, Eero K. 1935. Éléments De Finnois. Textes, Grammaire, Vocabulaire Première Année. Helsinki: Suomalainen Kirjallisuuden Seura.

Peltonen, Matti 1998. Omakuvamme murroskohdat. Maisema ja kieli suomalaisuuskäsitysten perusaineksina. - Pertti Alasuutari, Petri Ruuska (Toim.), Elävänä Euroopassa. Muuttuva suomalainen identiteetti. Tampere: Vastapaino, 19-34.

Pesonen, Sari, Marjut Vehkanen 2016. Finskan. Lättare än du tror. 6., uusittu painos. Helsinki: Edita Publishing Oy.

Remes, Hannu 2010. Johannes Aavik viron kielen sanaston kehittäjänä. - Tuglasseuran esitelmä 10.2.2010.

Richards, Jack C., Theodor S. Rodgers 2001. Approaches and Methods in Language Teaching. Second edition. Cambridge: Cambridge University Press.

Riihonen, Harald (Toim.) 1929. Lukukirja ja sanasto suomenkielen opiskelijoille. Leningrad: Kustannusosuuskunta Kirja.

Rojola, Lea 1999. Vastakohtien sekasortoinen maailma. - Lea Rojola (Toim.), Järkiuskosta vaistojen kapinaan. Suomen kirjallisuushistoria 2. SKS:n toimituksia 724:2. Helsinki: Suomalainen Kirjallisuuden Seura, 108-135.

Salokangas, Raimo 2003. Itsenäinen tasavalta. - Seppo Zetterberg (Toim.), Suomen historian pikkujättiläinen. Helsinki: WSOY, 678-686. 
Saukkonen, Pauli 2001. Maailman hahmottaminen teksteinä. Tekstirakenteen ja tekstilajien teoriaa ja analyysia. Helsinki: Yliopistopaino.

Setälä, Eemil Nestor, Vilho Setälä 1934. Linguaphone keskustelukurssi Suomi. Lontoo: Linguaphone Instituutti.

Sulkunen, Irma 2004. Suomalaisen Kirjallisuuden Seura 1831-1892. SKS:n toimituksia 952. Helsinki: Suomalainen Kirjallisuuden Seura.

Suni, Minna 2008. Toista kieltä vuorovaikutuksessa. Kielellisten resurssien jakaminen toisen kielen omaksumisen alkuvaiheessa. Jyväskylä Studies in Humanities 94. Jyväskylä: Jyväskylän yliopisto.

Szinnyei, József 1895. Finn Olvasókönyv mondattani példatárral. Budapest: Hornyánszky Viktor Kiadása.

Szinnyei, József 1916. Finn Olvasókönyv. Nyelvtani példatárral. Finnugor Kézikönyvek. II. Ötödik kiadás. Budapest: Hornyánszky Viktor Kiadása.

Tanner, Johanna 2012. Rakenne, tilanne ja kohteliaisuus. Pyynnöt S2 -oppikirjoissa ja autenttisissa keskusteluissa ['Linguistic structures, situation and politeness: requests in Finnish as a second language text- books and in authentic service encounters']. Helsingin yliopisto: suomen kielen, suomalaisugrilaisten ja pohjoismaisten kielten ja kirjallisuuksien laitos.

Tapana, Pentti 2003. Maantiedettä, ideologiaa ja idealismia. Suomi kansakoulun maantiedon oppikirjoissa 1900-1939. Turku: Turun yliopisto.

Tuomi, Jouni, Anneli Sarajärvi 2013. Laadullinen tutkimus ja sisällönanalyysi. 10. uudistettu painos. Helsinki: Tammi.

Tuomikoski, Aune, Helen Deans 1952. Elementary Finnish. Texts, Grammar, Glossary. Translated and adapted from Eero K. Neuvonen's Éléments de Finnois. Helsinki: Suomalainen Kirjallisuuden Seura.

Vaarala, Heidi 2009. Oudosta omaksi. Miten suomenoppijat keskustelevat nykynovellista? Jyväskylä Studies in Humanities 129. Jyväskylä: Jyväskylän yliopisto.

Vehkanen, Marjut 2015. Kieliopista kommunikaatioon. Suomi toisena ja vieraana kielenä -oppikirjat vuosina 1866-1953. Helsinki: Unigrafia Oy.

Vehkanen, Marjut 2017. Kaksi tapaa opettaa suomea vieraana kielenä - Johannes Aavik (1902) Praktilik Soome keele õpetus ja Béla Györffy (1939) Gyakorlati Finn Nyelvkönyv. - Lähivõrdlusi. Lähivertailuja 27, 242-277. http://dx.doi. org/10.5128/LV27.08

Virrankoski, Pentti 2012. Suomen historia. Maa ja kansa kautta aikojen. Helsinki: Suomalainen Kirjallisuuden Seura. 


\title{
The relationship of the text contents of the Finnish as a foreign language textbooks with the phenomena of their own time: Johannes Aavik Praktilik Soome keele õpetus (1902) and Béla Györffy Gyarkorlati Finn Nyelvkönyv (1939)
}

\author{
MARJUT VEHKANEN \\ University of Helsinki
}

My paper concerns the contents and user groups of two textbooks, those of Johannes Aavik (1902) Praktilik Soome keele õpetus (A practical textbook of Finnish) and Béla Györffy (1939) Gyokorlati Finn Nyelvkönyv (A practical Finnish textbook). I will look at the relationship between the contents of these textbooks and the phenomena of the time they were written. From a cultural-historical point of view, I seek solutions in the textual content of the books that refer to linguistic relationships or possible confluences with historical realities at the time the books were published $(1902,1939)$.

My aim is to open up perspectives to the authors' thought and learning concepts by means of a comparison of the themes of text contents, as well as to possible special assignments set for the books at their publishing time. The authors are linked to their own time, in this case by the time of publication of the textbook and by the reality of the writing process and the requirements it has created.

What in particular can be said about the contents of the texts in these books? In the Hungarian textbook there is a strong emphasis on religious content, as it was intended for students of the Lutheran church. The Estonian textbook has many fragments of Finnish fiction (Juhani Aho), Finnish songs (Maamme, the national anthem) and also many features of Finnish nationalism due to the difficult Russian grand duchy time. Beforehand I had thought that the texts in the Hungarian textbook were completely disregarding the historical reality of that time (the year 1939), but after reading one particular chapter at the end of the book I realized that the writer was full of worries surrounding him and Europe. 
Keywords: Finnish as a foreign language; the contents of L2 textbooks; L1; Estonian; Hungarian

\section{Marjut Vehkanen}

Helsingin yliopiston suomen kielen, suomalais-ugrilaisten ja pohjoismaisten kielten ja kirjallisuuksien laitos

Runeberginkatu 39 A 46

00100 Helsinki, Finland

marjut.vehkanen@helsinki.fi 